\title{
ACTIVE POINT BAR DEVELOPMENT AND RIVER BANK EROSION IN THE INCISING CHANNEL OF THE LOWER TISZA RIVER, HUNGARY
}

\author{
GABRIEL JONATHAN AMISSAH ${ }^{1 *}$, TÍMEA KISS ${ }^{1}$, KÁROLY FIALA ${ }^{2}$ \\ ${ }^{1}$ Department of Physical Geography and Geoinformatics, University of Szeged; Hungary \\ ${ }^{2}$ Lower Tisza Water Directorate; Hungary \\ *Email: gabbyjonad@yahoo.com
}

Received 22 November 2019, accepted in revised form 20 December 2019

\begin{abstract}
The development of point-bars and bank erosion are critical near-bank processes, as they indicate the sediment and hydraulic regime of a river system, thus, they refer to the equilibrium conditions of a channel. However, throughout history, rivers have been modified for various benefits which change the development of point-bars and the rate of bank erosion. In the Lower Tisza River (Hungary), river regulations influenced the channel and floodplain development, altering the natural fluvial processes. The aim of the research was to determine the rate of near-bank processes and to make trajectory for future river evolution to support future engineering works. The bank erosion and point-bar development at human-influenced and freely meandering sections of the Tisza River were monitored since 2011. Behind a collapsed revetment, the bank erosion rate was $0.6 \mathrm{~m} / \mathrm{y}$, while at a freely meandering section it was $2.3 \mathrm{~m} / \mathrm{y}$. The studied point-bars are located in revetted and freely meandering sections. Their surface eroded within the period. These intensive erosional processes refer to an incising meandering channel, which must be considered during future planning of in-channel structures (e.g. revetments, bridges), thus, geomorphic methods must be considered in any river engineering scheme.
\end{abstract}

Keywords: point-bar development, bank erosion, incising channel, human impact, Lower Tisza River

\section{Introduction}

The development of point-bars and bank erosion are characteristic processes in meandering alluvial rivers, reflecting the equilibrium condition of rivers (Church and Rice, 2009; Schuurman et al., 2016). They play crucial roles in meander development and ultimately, in the evolution of floodplains (Thorne, 1991; Nicoll and Hickin, 2010; Hagstrom et al., 2018; Moody, 2019). While floodplains are considered to be the result of vertical aggradation (related to overbank floods) and horizontal accumulation in the form of point-bar development and channel narrowing (Hickin, 1969), bank erosion modifies floodplains through enhanced meander migration (Thorne, 1991). In a typical equilibrium channel, although active point-bar development and bank erosion are present, the changes in crosssectional area and shape are negligible for the given set of flow conditions (Hickin, 1969). Thus, lateral accretion in the form of point-bar development and lateral bank erosion complement each other in an equilibrium river system. Riverbank erosion has the added advantage of being a relatively rapid process compared with other geomorphological processes, hence making it crucial in understanding changes in the river's landscape (Hooke, 1980).

Although these processes are critical in better understanding the spatial evolution of rivers, they have had different research 
histories. Lawler (1993) indicated that, although the study of river bank erosion was previously neglected, lately, it has become an important focus of research, cutting across various disciplines including geomorphology, geology, hydrology, ecology and engineering (Wallick et al., 2006; Lai and Greimann, 2008; Rinaldi et al., 2008; Luppi et al., 2009; Blanckaert et al., 2012; Nagata et al., 2014; Iwasaki et al., 2016; Rusnák et al., 2016). While research in bank erosion is not limited to geomorphology, the knowledge of the rates of bank erosion is of value in investigating the effects of human activities on channel processes which is important for river management (Kis and Lóczy, 2018; Bertalan et al., 2019).

Likewise, point-bars have been the subject of various research (Dietrich and Smith, 1983; Hodskinson and Ferguson, 1998; Pyrce and Ashmore, 2005; Ikeda, 2013; Kasvi et al., 2013; Eke et al., 2014; Ghinassi et al., 2016; Wu et al., 2016; Cosma et al., 2019). The complex interplay of low-frequency high flows, and the quality and quantity of sediments, as well the geometry of rivers are significant in the deposition and erosion of a pointbar, just as in many other fluvial processes (Galia and Škarpich, 2013; Hagstrom et al., 2018; Moody, 2019). The location of a pointbar within the river system (upstream or downstream) also plays an important role in its development (Ghinassi et al., 2016).The important interplay of the processes involved in bank erosion and point-bars leads to the growth of meanders in rivers. While bankfull discharge is mainly responsible for rigorous erosion, the transportation of the eroded sediments by secondary currents to the zone of low shear stress and velocity, at the convex bank, results in deposition and development of point-bars (Dietrich and Smith, 1983; Eke et al., 2014).

The Lower Tisza River like many other European rivers, has been subjected to various forms of human interventions: artificial levees were built to disconnect the river channel from its floodplains, artificial meander cutoffs were made to reduce the duration of floods, and bank stabilization measures including revetments and groynes were constructed ( Kiss et al., 2008; Amissah et al., 2018). The river as a result has transformed from a meandering river to an incising meandering one (incision has lowered base level while maintaining the meandering pattern with high bank walls), as it strives to re-establish a new equilibrium after the river training ( Kiss et al., 2008; Amissah et al., 2018). In recent times, some studies have shown that although the flood hazards have reduced due to higher flood velocities, there are threats to artificial levees due to increased lateral erosion (Kiss et al., 2019). Further research on the factors generating bank instability have also established the high magnitudes and various types of bank erosion in the Lower Tisza (Kis and Lóczy, 2018). To understand the equilibrium state of the river and the hazards posed by the evolution of the river, this study sought to measure the rate of bank erosion; and to determine the net sediment storage dynamics of active point-bars.

\section{Study area}

The studied Lower Tisza is the $89-\mathrm{km}$ downstream section of the Tisza River between Csongrád (255 r.km) and the Hungarian-Serbian border (166 r.km). Its length was reduced by one third by artificial cutoffs in the late $19^{\text {th }}$ century. The shortened river and the subsequent doubled slope caused an increase in stream power which resulted in rapid channel incision (Amissah et al., 2018). Simultaneously, the wide natural floodplain (ca. $10 \mathrm{~km}$ ) was reduced to just $1 \mathrm{~km}$ by constructing artificial levees. To protect the artificial levees in the $20^{\text {th }}$ century, the construction of revetments was necessary, which accelerated the channel incision and transferred the bank erosion to the unrevetted downstream sections (Kiss et al., 2019). The absolute water stage at Csongrád is $1394 \mathrm{~cm}$ (least stage: -357 $\mathrm{cm}$ and highest stage: $1037 \mathrm{~cm}$ ). The Lower Tisza is a typical lowland river with a clayey 


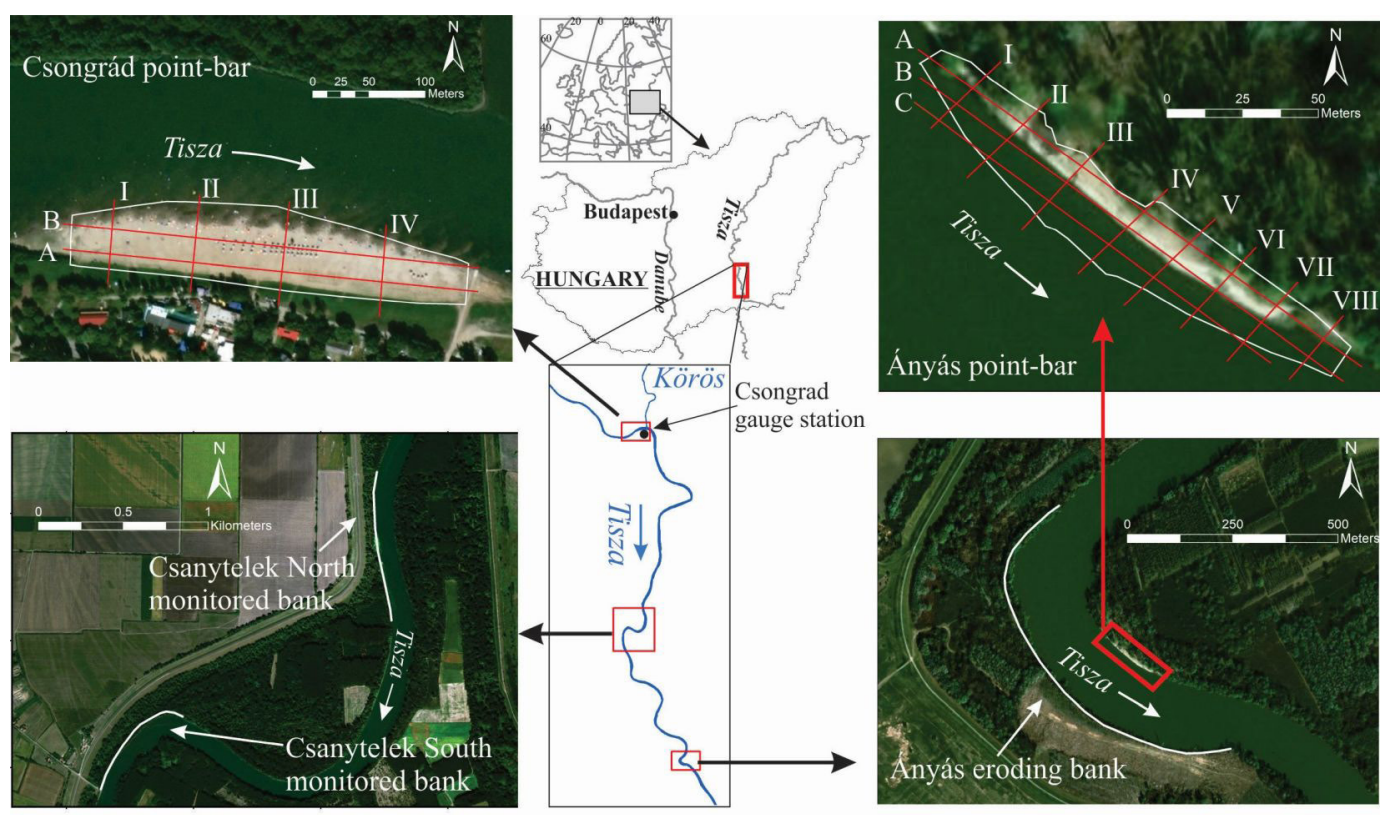

Longitudinal and transverse sections through point-bars

Fig. 1. Bank erosion was measured at three sites, while the point-bars development was measured at two locations. On the point-bar surfaces, longitudinal profiles(A-C) and transverse profiles (I-VIII) were analyzed

bed, and has a high suspended sediment transport (18.7 million t/y) composed generally of fine-grained sands and silt. According to Sipos et al. (2007), the Tisza has a relatively low bedload transport ( $9000 \mathrm{t} / \mathrm{y}$ ). Although two major floods usually occur on the Tisza (in March-April due to snow melt; and in June due to early summer rainfall), the summer floods sometimes superimpose on the preceding spring flood; thus, high floods could occur (Lászlóffy, 1982; Kasse et al., 2010; Mezősi, 2017)

To quantify and understand bank erosion of the Lower Tisza River, three eroding sections along the western bank were selected (Fig.1). The upstream 0.8 and $0.6 \mathrm{~km}$ long sections represent banks with revetments (Csanytelek North: 227.4-226.6 r.km, and Csanytelek South: 224.7-224.1 r.km), while the $1.1 \mathrm{~km}$ long downstream study area is free of any direct human impacts (Ányás: 212.2-211.1 r.km).
In its natural state, before the regulations, the sinuosity of the channel was high (with up to 30 meander bends), point-bars appeared in every bend, and the channel was relatively shallow (6-8 $\mathrm{m})$. Along the entire Lower Tisza in the late $19^{\text {th }}, 47$ point-bars existed (in $52.3 \mathrm{~km}$ length), but nowadays, their number (20) and total length (4.7 km) have reduced considerably (Kiss et al., 2019). For this study, point-bars which were not dredged, and develop in a quasi-natural way were selected (Fig.1). The upstream pointbar (Csongrád: 244.1-243.6 r.km) developed at a confluence, thus it could also be considered as a confluence bar. Its opposite bank is revetted, thus it might influence the evolution of the point-bar. However, the studied downstream point-bar evolved in a natural, but sharp meander without direct human impact (Ányás: 211.8-211.5 r.km). Here, the bank erosion on the opposite bank was also measured. 


\section{Materials and Methods}

To understand the role of bank erosion and point-bars in the morphological evolution of the Lower Tisza River, changes in banklines and point-bar elevation were measured and analyzed.

The bank erosion was studied by measuring the bank-line changes with Topcon GNSS RTK Hiper Pro system. The measurements started in 2011 at Ányás, while that at Csanytelek began in 2013 (horizontal accuracy: $\pm 1 \mathrm{~cm}$ ). The data were analyzed using ArcGIS 10.3. The mean bank erosional rate was calculated based on the mean width of the polygon between two bank-lines.

The recent evolution of point-bars was monitored with Topcon GNSS RTK Hiper Pro system. The measurements started in 2012 (vertical accuracy: $\pm 1 \mathrm{~cm}$ ). The surveys were performed along cross-sectional profiles, surveying 850-1600 points at each location with an average interval of $4 \mathrm{~m}$ between successive points in the transverse direction and $10 \mathrm{~m}$ in the longitudinal direction. Based on the data, digital elevation models (DEM) were created (ArcGIS 10.3) using the Kriging interpolation method at a resolution of $1 \mathrm{~m}$. The volume of the bar at a given survey was measured from $73.5 \mathrm{~m}$ a.s.l at Csongrád while at Ányás, it was measured from $74 \mathrm{~m}$ a.s.l. To evaluate the changes in sediment dynamics, the subsequent DEMs were extracted from each other, and longitudinal and cross- sectional profiles were analyzed (Fig. 1).

The changes were related to the daily stage changes at Csongrád gauging station. The upstream point-bar is submerged at 144 cm water stage, while the point-bar at Ányás is covered by much higher $(434 \mathrm{~cm})$ stages (Fig. 2).

\section{Results}

\section{Hydrological changes of the studied period}

The hydrological conditions of the studied sections of the Lower Tisza within the studied period is reflected in the water stages from the Csongrád gauge station (Fig. 2). The period (2011-2019) was characterized by mainly low stages $(<0 \mathrm{~m})$, which occurred in $53 \%$ of the record (Table 1 ).

The measured eroding banks had a mean elevation of $81.5 \mathrm{~m}$ a.s.l at Csanytelek North and South, and $82 \mathrm{~m}$ a.s.l at Ányás. Due to the similarity in elevation of the banks, we assumed that similar hydrological conditions influenced their evolution. At Csanytelek North and South banks bankfull stages were reached only within five out of nine years over the studied period for 2-7 weeks. The bank monitored at Ányás on the other hand, experienced shorter overbank stages by 1-6 weeks, because the bankline of this site is much higher due to the development of a natural levee.

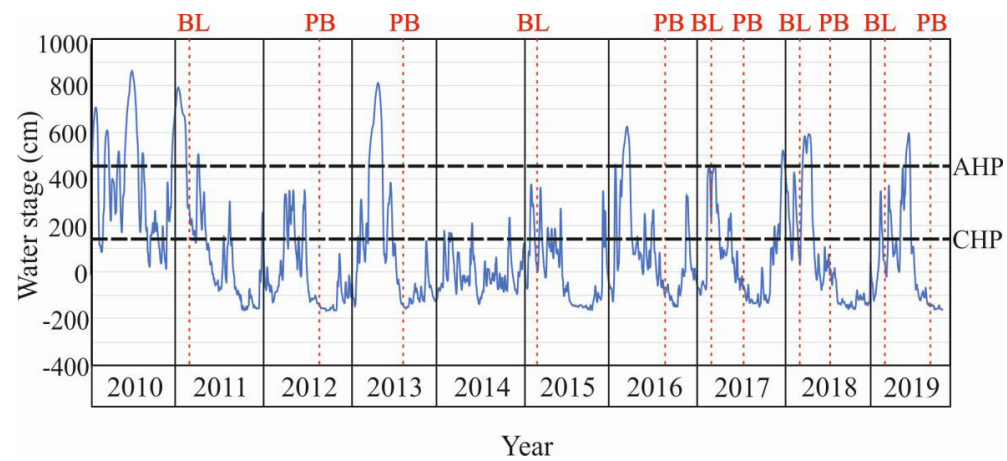

Fig. 2. Daily water stages (2010-2019) measured at the Csongrád gauge station. The survey times of point-bar (PB) and banklines (BL) are indicated. Water stages (dashed lines) when the point-bars at Csongrád (CHP) and Ányás (AHP) are submerged are represented 
Table 1 . Frequency of low stages $(<0 \mathrm{~cm})$, overbank stages $(\geq 550 \mathrm{~cm})$, and inundation of point-bars (130-450 cm) between 2011 and 2019 at the Csongrád gauging station

\begin{tabular}{cccccc}
\hline \multirow{2}{*}{ Year } & \multicolumn{5}{c}{ Annual duration (days) } \\
\cline { 2 - 6 } & Low stages & \multicolumn{2}{c}{ Overbank stages } & \multicolumn{2}{c}{ Inundation of point-bar } \\
\cline { 2 - 6 } 2011 & 167 & Csanytelek & Ányás & Csongrád & Ányás \\
2012 & 256 & 0 & 32 & 131 & 42 \\
2013 & 187 & 51 & 0 & 60 & 0 \\
2014 & 229 & 0 & 45 & 110 & 57 \\
2015 & 204 & 0 & 0 & 29 & 0 \\
2016 & 144 & 24 & 0 & 71 & 0 \\
2017 & 178 & 0 & 14 & 101 & 32 \\
2018 & 197 & 28 & 0 & 104 & 39 \\
2019 & 154 & 12 & 9 & 101 & 18 \\
\hline
\end{tabular}

Based on the hydrological data over the studied period, the Csongrád point-bar is usually submerged for 2-3 months. During the studied period this point-bar was inundated for the longest time in 2011 (131 days), while in 2014 it was submerged only for 29 days. On the contrary, the point-bar at Ányás is totally submerged just for shorter periods (0.5-2 months), it experienced the longest inundation (57 days) in 2013, while water could cover its entire surface just for 13 days in 2017.

\section{Bank erosion}

The bank erosion of the monitored sections of the Lower Tisza River differed both in extent and magnitude (Fig. 3). The bankline experienced minimal erosion at Csanytelek South because of the existence of a revetment, but there was medium erosion rate at Csanytelek North (mean: $0.79 \mathrm{~m} / \mathrm{y}$ ), and high bank retreat was measured at the freely meandering Ányás bend (mean: 1.29 $\mathrm{m} / \mathrm{y}$ ).

The erosion rates at Csanytelek North
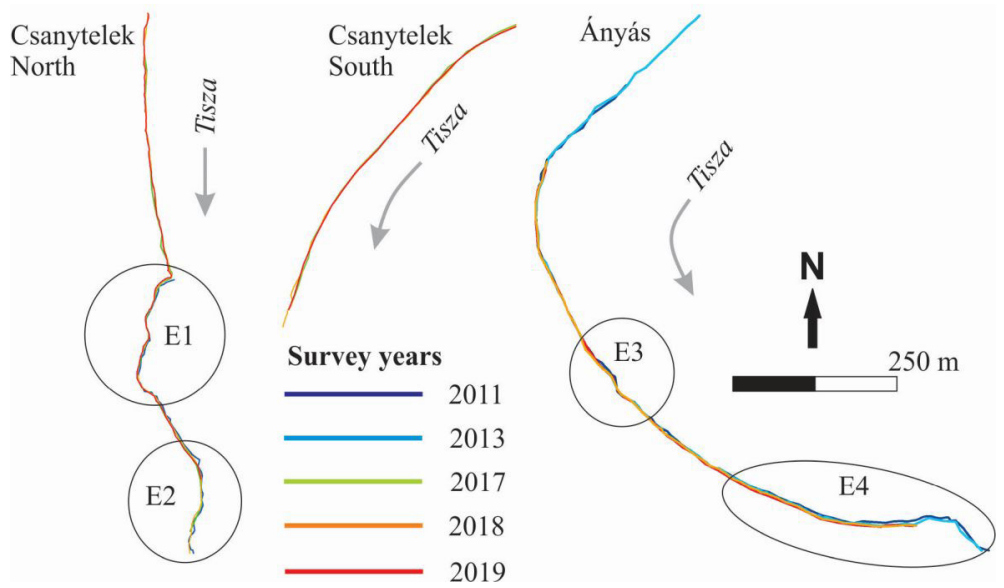

Fig. 3. Changes in banklines at the monitored banks 

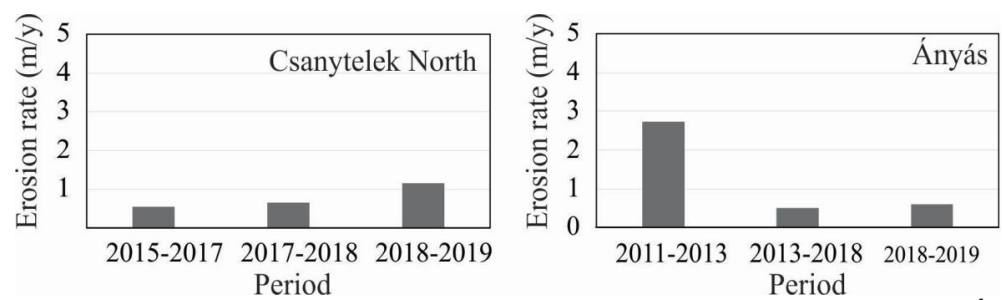

Fig. 4. Annual mean bank erosion rates $(\mathrm{m} / \mathrm{y})$ measured at Csanytelek North and Ányás bend

and Ányás differed both in magnitude and temporality (Fig. 3-4). The erosion rate gradually increased at Csanytelek North, thus compared to the first period (2015-2017) when the mean erosion rate was $0.56 \mathrm{~m} / \mathrm{y}$, it doubled to $1.12 \mathrm{~m} / \mathrm{y}$ in $2018-2019$. The erosion rate $(0.67 \mathrm{~m} / \mathrm{y})$ in the intermediate period (2017-2018) showed only a slight increase (ca. 20\%) compared to the first period. At Ányás, the bank erosion rate had an inverse trend. Between 2011 and 2013 the bank eroded by a high rate $(2.75 \mathrm{~m} / \mathrm{y})$, the next period (2013-2018) was characterized by $82 \%$ reduction in the rate to $0.51 \mathrm{~m} / \mathrm{y}$.
Between 2018 and 2019 however, there was a $20 \%$ increase in the rate $(0.61 \mathrm{~m} / \mathrm{y})$.

Spatially, the erosion rate was quite uniform both at Csanytelek North and Ányás, though some sections were more affected by erosion (E1-4) than the others (Fig. 3). Intense erosion $(1.2 \mathrm{~m} / \mathrm{y})$ at Csanytelek North occurred at two locations. At E1, bank erosion was initiated by the collapse of the downstream end of the placed-rock revetment. The exposed and steep (ca. $30^{\circ}$ ) bank then failed through bank scouring, and a mix of failure and slips. At E2, the bank is gentler (ca. $20^{\circ}$ ) and erosion takes place in

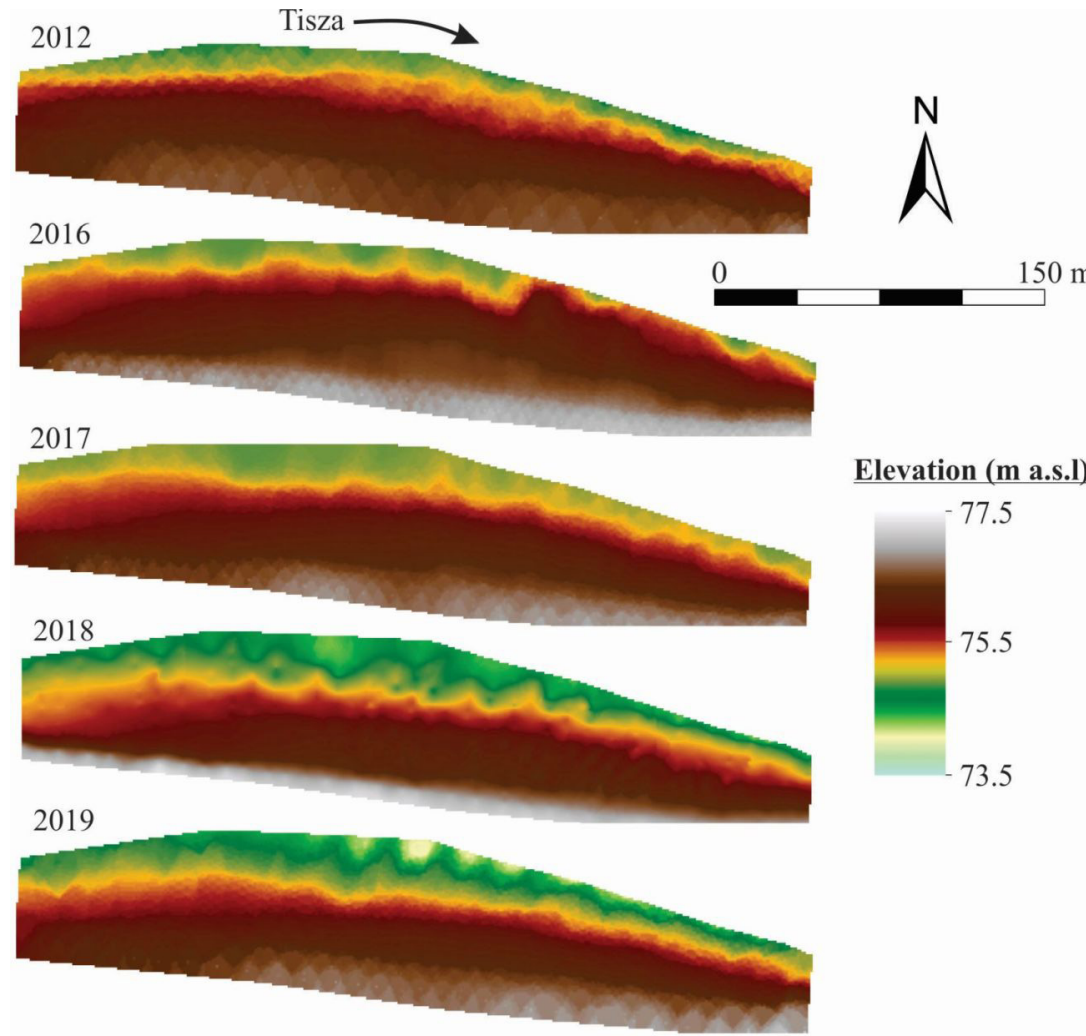

Fig. 5. The digital elevation model of the point-bar at Csongrád in the surveyed years 


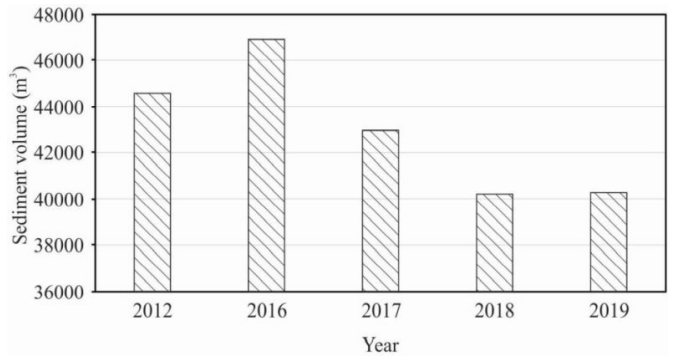

Fig. 6. Sediment volume (above $73.5 \mathrm{~m}$ a.s.l.) of the Csongrád point-bar in the surveyed years

the form of scouring and creeping.

At Ányás bend also, the downstream section (E3 and E4) of the monitored bank had intense erosion $(2.4 \mathrm{~m} / \mathrm{y})$. Here the bank was steeper (ca. $50^{\circ}$ ) and the bank failed mainly through slips with trees on the slumped material. In the steepest locations toppling failure occurred with fallen trees which collapsed into the channel with the bank material.

\section{Point-bar evolution}

The point-bar at Csongrád is quite flat (Fig. 5), as its elevation was between $73.5 \mathrm{~m}$ a.s.l and $77.5 \mathrm{~m}$ a.s.l during the studied period. The volume of the point-bar (above $73.5 \mathrm{~m}$ ) ranged between 40-47 thousand $\mathrm{m}^{3}$ (Fig. 6). Both the changes in the elevation of the bar surface and its volume reflects the dominance of erosion (Fig. 6-7). The point-bar generally eroded since the first survey in 2012 to 2019 , thus the changes in sediment volume refers to net erosion by $9.6 \%$, thus the volume of sediment decreased by $4260 \mathrm{~m}^{3}$. However, there was net accumulation between 2012 and 2016 (gain: $2338 \mathrm{~m}^{3}$ ), and again a slight aggradation $\left(87 \mathrm{~m}^{3}\right)$ from 2018 to 2019 . However, in-between these years the volume of the bar decreased by $3929 \mathrm{~m}^{3}$ (20162017) and later by $2755 \mathrm{~m}^{3}$ (2017-2018). The changes in the sediment volume were translated into changes in the mean elevation

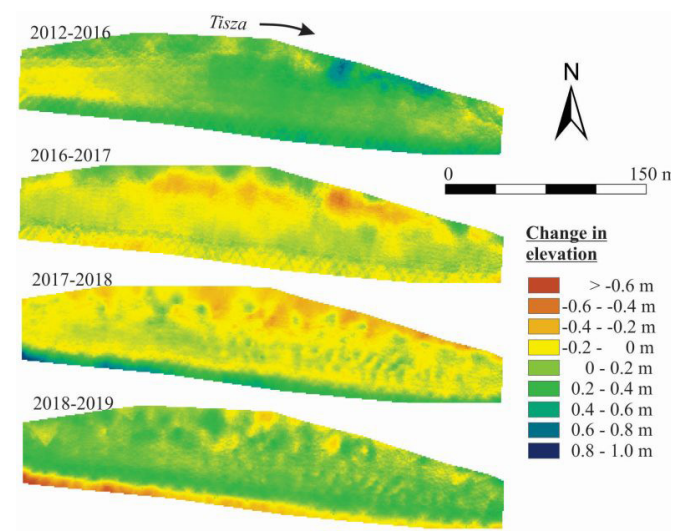

Fig. 7. Elevation changes of the surface of the point-bar at Csongrád. Negative values refer to erosion, positive ones to accumulation

of the point-bar (Fig. 7). In the first period (2012-2016), the aggradation increased the mean elevation of the bar by $0.11 \mathrm{~m}$, especially in the downstream half of the bar, reflecting its slight migration. However, in the subsequent years, the bar became lower by $0.16 \mathrm{~m}$ (2016-2017) and further by $0.19 \mathrm{~m}$ (2017-2018). Almost the entire area of the bar was eroding, but especially the low-lying areas located close to the wetted channel. Finally, there was a minor increase in the mean elevation $(<0.01 \mathrm{~m})$ of the point-bar from 2018 until 2019. At this time, the higher surfaces gained some sediment and the area close to the wetted channel eroded further on.

The spatial and temporal variations of the point-bar at Csongrád are also indicated by the longitudinal and transverse profiles (Figs. 8-9). The longitudinal profiles reflect, that the lower zone ( $<75.5 \mathrm{~m}$ a.s.l.) of the bar had a convex shape, with the middle part having the highest elevation (Fig. 8, section B). The bar surface had quite smooth upstream part, but ripples developed on its downstream part. On both areas there was a generally even erosion, though in the period of 2016-2018, an erosion of almost $1 \mathrm{~m}$ took place on the lower regions of the bar. The bar surface was higher (>75.5 $\mathrm{m}$ a.s.l.) along the bankline (Fig. 8, section A). Here, the bar had quite smooth surface, with maximum 

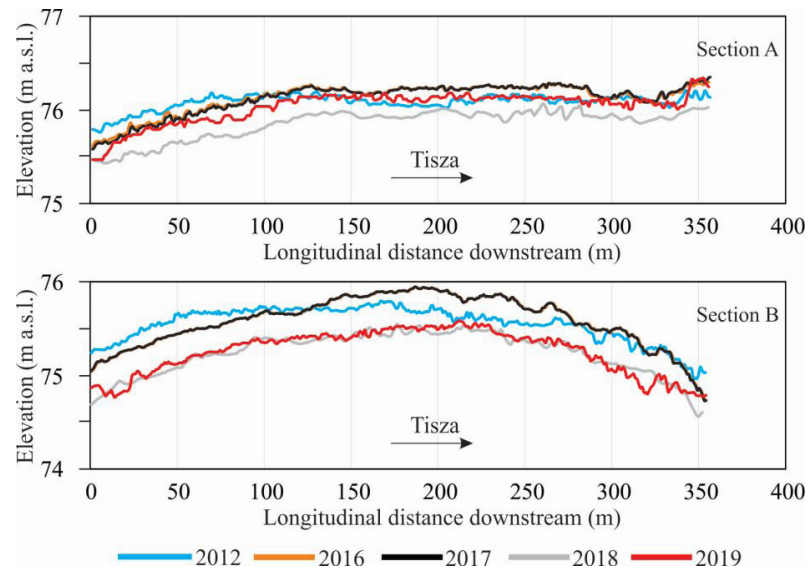

Fig. 8. Spatial and temporal variation of longitudinal profiles (A-B) of the Csongrád point-bar (location of the profiles is indicated in Fig.1)

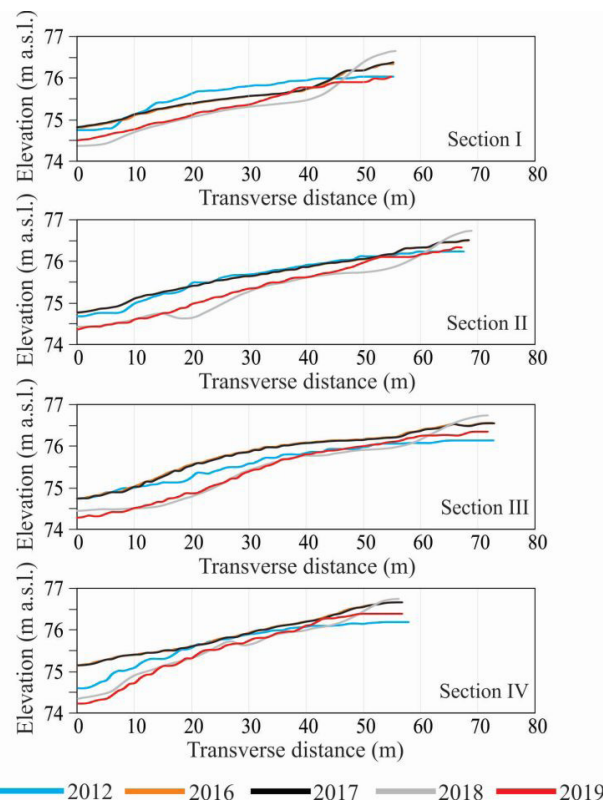

Fig. 9. Spatial and temporal variation of the transverse profiles (I-IV) of the Csongrád point-bar (location of the profiles is indicated in Fig.1)

erosion being generally less than $0.40 \mathrm{~m}$. The greatest was measured on the upstream end, reflecting downstream bar migration. The downstream end had less changes but remained higher than the upstream end although there were fluctuations over the studied period. The transverse profiles reflect that the higher zone of the bar has generally convex slopes (Fig. 9), however the low-lying parts have various slope profiles. While the upstream profile has straight slope (Fig. 9, Section I), the downstream profiles (Section II-IV) show convex shapes reflecting aggradation processes. The gradual downstream migration of the bar is well visible on these profiles, as Section II had originally a convex profile, but it became straightened, while the further downstream profiles have increasingly convex shape.

The downstream point-bar at Ányás stretches from $74.0 \mathrm{~m}$ a.s.l. to $86.0 \mathrm{~m}$ a.s.l. (Fig. 10 ). The volume of the point-bar (measured 


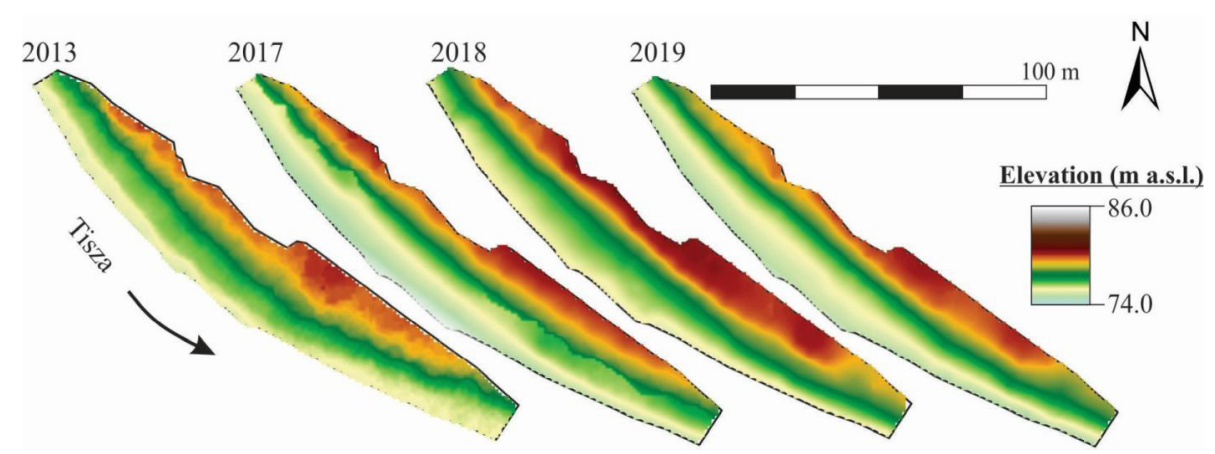

Fig. 10. The digital elevation model of the point-bar at Ányás in the surveyed years

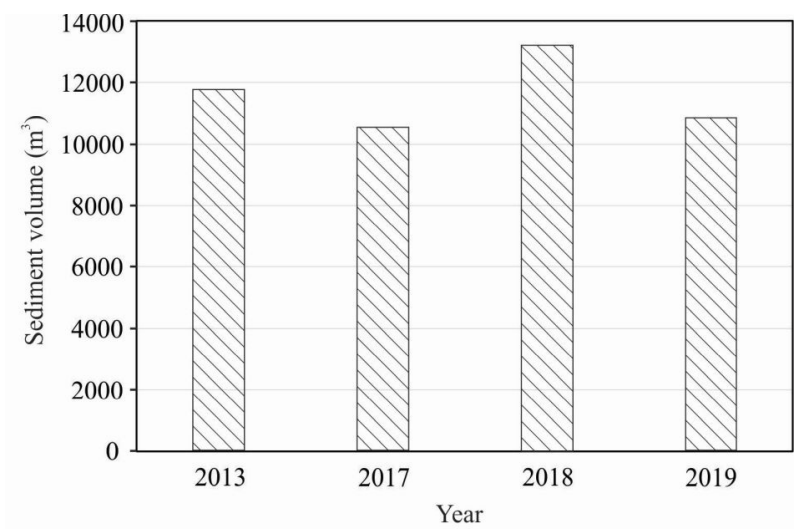

Fig. 11. Sediment volume (above $74.0 \mathrm{~m}$ a.s.l) of the Ányás point-bar in the surveyed years

above74.0 $\mathrm{m}$ a.s.l.) ranged between 10.513.3 thousand $\mathrm{m}^{3}$ (Fig. 11), thus its volume is just $20-33 \%$ of the point-bar at Csongrád, because it is shorter and narrower than its upstream counterpart. High volumes were measured in $2013\left(11747 \mathrm{~m}^{3}\right)$ and in 2018 $\left(13232 \mathrm{~m}^{3}\right)$, though in 2017 and 2019 the volume of the bar decreased to $10517 \mathrm{~m}^{3}$ and $10818 \mathrm{~m}^{3}$ respectively. Thus, the pointbar lost $1230 \mathrm{~m}^{3}$ (2017) and $2414 \mathrm{~m}^{3}$ (2019) of sediments respectively, which means ca. $20 \%$ volume lost compared to the previous period. However, in the period of 2017-2018, a similar rate of sediment gain was detected $\left(2715 \mathrm{~m}^{3}\right)$. The changes in sediment volume is reflected also by the pattern of net erosion and net deposition (changes in elevation) between the survey years (Fig. 12). Between 2013 and 2017 the mean height decreased by $0.35 \mathrm{~m}$, especially in three areas: in the nearto-the-bankline zone, and in the middle of the bar, though slight accumulation was detected in its downstream end. The surface became higher by $0.76 \mathrm{~m}$ in $2017-2018$, especially the in the upstream parts and close to the water. Finally, the bar's surface became lower by $0.69 \mathrm{~m}$ (2018-2019), indicating cyclic erosional-depositional pattern.

The changes in the height of the bar are further highlighted by the longitudinal and transverse profiles (Fig. 13-14). The cyclic erosion and aggradation of the point-bar involves ca. $1 \mathrm{~m}$ change in elevation. The point-bar referred general erosion over the period 2013-2019 especially in its lower zone (<76 $\mathrm{m}$ a.s.l.), having a gradual downstream shift in the highest point of the zone (Fig 13: section $\mathrm{C}$ ). The middle zone (76-78 $\mathrm{m}$ a.s.l.) is also characterized by erosion, however there was a slight net aggradation at the downstream end of the bar, and its higher central region also migrated downstream (Fig. 13: section B). The upper surfaces (>78 $\mathrm{m}$ a.s.l.) had aggradation at both the downstream and upstream ends of the pointbar (Fig 13: section A). 


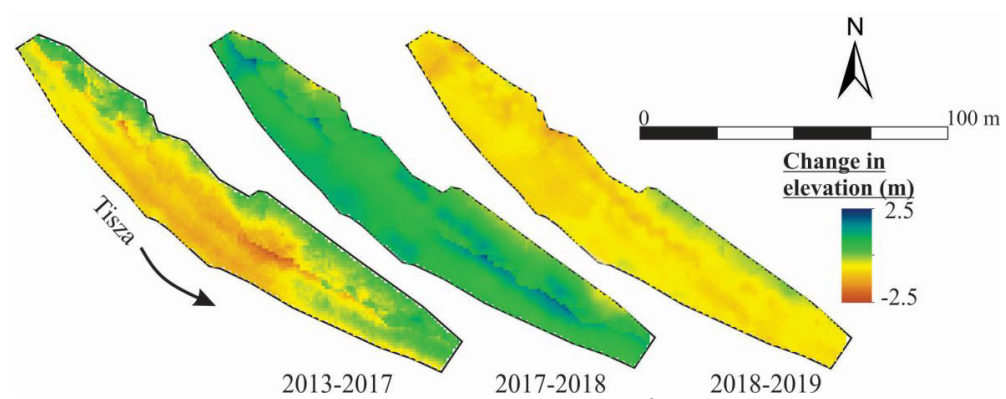

Fig. 12. Elevation changes of the surface of the point-bar at Ányás. Negative values refer to erosion, positive ones to accumulation
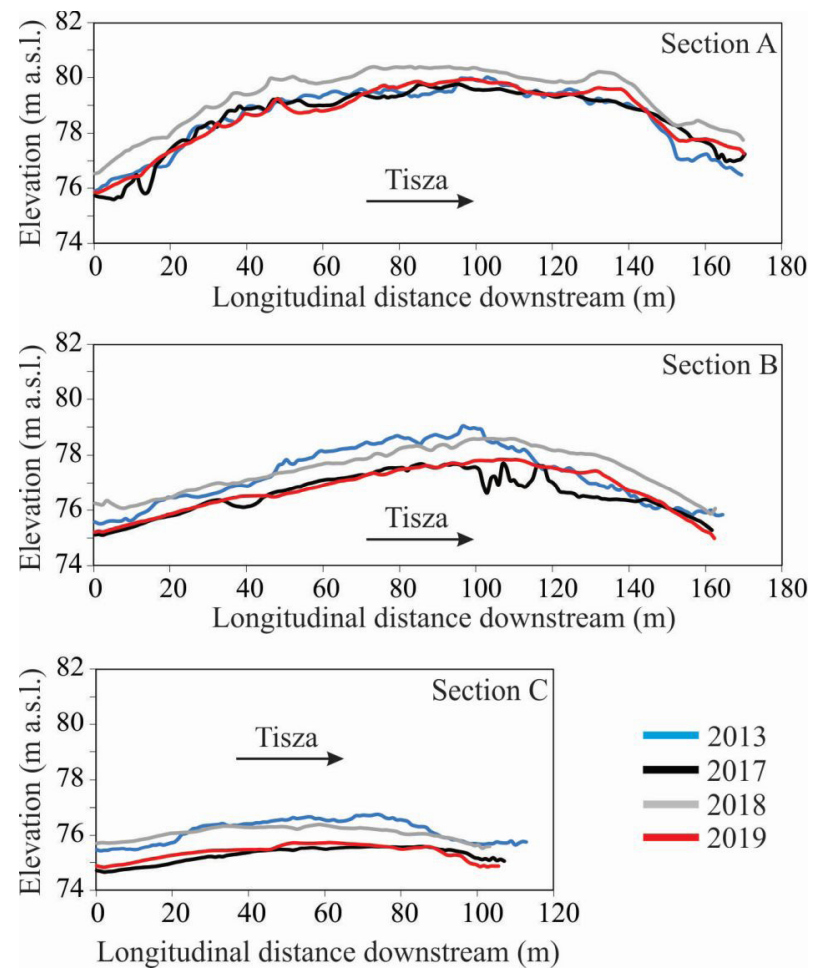

Fig. 13. Spatial and temporal variation of longitudinal profiles (A-C) at the Ányás point-bar (location of the profiles is indicated in Fig.1)

The transverse profiles reflect deposition on the downstream ends of the point-bar even more visibly (Fig. 14). The upstream profiles (I-IV) had very characteristic concave slopes on the middle zone of the bar, especially at the time of the first survey (2012). Later this area started to accumulate, thus straight slopes evolved, though the highest zone still faced erosion. Later (2017-2018), although there was aggradation over the whole pointbar, the highest gains were at the upstream end, and in the lower zone of the bar. Erosion again characterized the period 2018-2019 but more uniformly than the period 20132017. The downstream transverse profiles (V-VIII) had mainly straight slopes; however, they turned into convex ones until 2019, referring to accumulation after an erosional period. Nowadays (2019), the lower zone has a mix of concave and convex profiles, while the higher elevations have straight or convex ones, referring to erosion in the lower zone and accumulation in the upper one. 

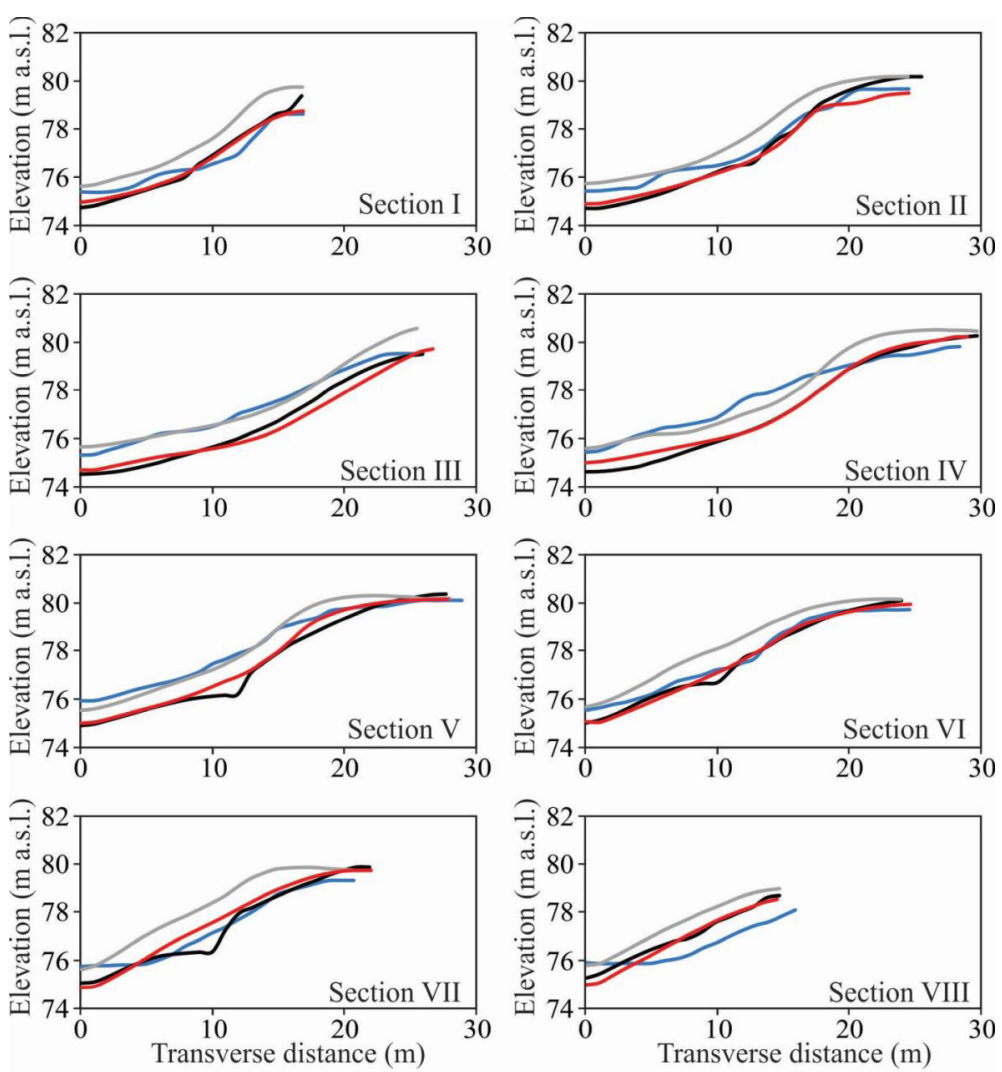

$2013 \longrightarrow 2017$

$-2018=2019$

Fig. 14. Spatial and temporal variation of the transverse profiles (I-VIII) at the Ányás point-bar (location of the profiles is indicated in Fig.1)

\section{Discussion}

\section{Bank erosion and its main influencing factors}

The bank erosion at Csanytelek North and Ányás were different, although they had similar hydrological conditions. The two sites had comparable bankfull stages both in magnitude and their durations. The bank erosion rate at Csanytelek North increased from 2013 to 2019, although the stages did not commensurate with it. This suggests that the processes of erosion within this section was not necessarily controlled only by the hydrological regime, although according to Hickin (1974), floods control most channel forming processes including bank erosion. The erosion within this section was probably controlled by high flow energy generated from high velocities due to the revetment, which was even distinguishable at low stage (Kiss et al., 2019). This increased flow energy was transferred to the downstream end of the revetted section where it was dissipated. It seems, that at Csanytelek North, the moderate stages were more suited to the erosion of the revetment and subsequent lateral erosion. As highlighted by Luppi et al. (2009), as moderate flow is a conducive hydrologic condition for this type of failure, the annual rates of erosion at Csanytelek North increased over the period 2015-2019, as greater and greater proportions of the revetment became mobilized.

At Ányás, the high and near-vertical banks failed mainly through circular slips and toppling failure (Kiss et al., 2019). This is usually through saturation of the bank material which lowers its angle of repose, 
and eventually failing through slip failure and toppling (Department of Natural Resources and Water, 2006). This mode of collapse was mostly accelerated with bankfull stages. High water stages therefore create perfect conditions for the initiation of failure in these high vertical banks as indicated by Luppi et al. (2009). The yearly rates of erosion decreased from 2011 to 2019 probably as a response to the reduction in the bankfull stages which occurred within the period. In spite of this, medium stages still created favorable conditions for the erosion through scouring of the toe of the banks, and eventually the bank collapsing into the channel. That notwithstanding, the absence of the bankfull stages affected the magnitudes of the erosion.

The human impacts at the three study areas are quite different. Although the western bank of the sections of the Lower Tisza at Csanytelek North and Csanytelek South are both revetted, the results indicated erosion at Csanytelek North while virtually no erosion was recorded at Csanytelek South. This indicates differences in the effectiveness of the bank stabilization at the two revetted sections. As indicated by the conceptual model of bank erosion and revetment collapse in the Lower Tisza River (Kiss et al., 2019), the construction of revetments along the banks of the Lower Tisza River increased flow velocities and as a result, high erosivity of flow. At Csanytelek South, the stepped-block revetment design deflected the flow energy resulting in no bank erosion. This was not the case at Csanytelek North however. The high erosivity initiated the collapse of the individual stones at the end of the placed-rock revetment within this river section. This collapse enhanced the lateral and vertical erosion of the exposed river bank with a new of the revetment formed. The process is repeated at the new end with an upstream propagation. While this process takes place, lateral and vertical erosion of the initial ends also continue thereby creating a three-dimensional erosional front: lateral (into floodplain towards levees), vertical (incision into channel bed thereby creating a local scour, and forming a pool together with the lateral erosion); and longitudinal (in the upstream direction, enhanced by the pool formed and eroding the revetment further). Although the construction of the revetment transferred stream power to the downstream end of the revetted sections, the placed-rock revetment at Csanytelek North failed due to the possibility of the rocks of the revetment to be eroded one by one. Currently, the bank erodes by $0.79 \mathrm{~m} / \mathrm{y}$ in average (max $1.16 \mathrm{~m} / \mathrm{y}$ ). As the artificial levee is just 25$50 \mathrm{~m}$ distance from the eroding bank, it will be vulnerable in 20-40 years. Previous studies however suggested as high as 3-6 $\mathrm{m} / \mathrm{y}$ erosion rates at banks with collapsed revetment along the Lower Tisza, making artificial levees vulnerable within just 8-15 years (Kiss et al., 2013, 2019). Downstream of the collapsed revetment, erosion was initiated by the increased flow velocities. The erosional processes within this section was mainly through direct corrosion which is controlled mainly by the flow conditions (Hooke, 1979).

The meander at Ányás is without direct human impact, thus, the process of bank erosion is different. With high and steep banks on the concave outer bank, circular slips are mainly responsible for the great erosion rate $(1.29 \mathrm{~m} / \mathrm{y}$ in average, max 2.75 $\mathrm{m} / \mathrm{y}$ ). The high banks with the steep slopes (ca. $50^{\circ}$ ) create the necessary conditions for the slips and toppling into the channel. This is mainly through thalweg incision as a result of the channel response to the various human interventions in the Lower Tisza (Amissah et al., 2017), thus, though this study area is not directly influenced by human impact, the propagating effects of the engineering works influence the processes here as well. The high erosion rates create failure blocks and slump debris in front of the eroding bank. The high flow velocities and the local turbulence are responsible for the erosion of sediment slump debris (Thorne, 1991). Thus, at low stages, the energy of the flow attacks the slumped material to satisfy the sediment transport capacity of the river. This reduces 
the actual energy available for bank and bed corrasion thereby reducing bank and bed erosion rates.

\section{Point-bar development and its influenc- ing factors}

The Csongrád point-bar has a lowerlying flat surface just like confluence bars, while the point-bar at Ányás is much higher. Therefore, the point-bar at Csongrád was entirely inundated for $16-36 \%$ of the periods, while at Ányás the total inundation of the point-bar was much shorter (0-16\%).

The erosion-dominant nature of the pointbar's sediment dynamics is reflected by the elevation decrease of their surfaces and by loss of their net volume, although their magnitudes differed. At Csongrád, the mean bar elevation was reduced by $0.20 \mathrm{~m}$ (20122019) while at Ányás it was reduced by 0.28 $\mathrm{m}$. As the relative height of the point-bar at Csongrád is only $2 \mathrm{~m}$ (at Ányás it is $11.5 \mathrm{~m}$ ), the erosion here is most spectacular, as the bar surface became inundated more often, causing problems for the tourists (smaller sandy beach, deeper water).

The changes in elevation at the point-bar of Csongrád were relatively higher in the years in which erosion was dominant $(0.19$ $\mathrm{m}$ and $0.13 \mathrm{~m}$ for 2016-2017 and 20172018 respectively). While the yearly changes between 2012 and 2016 were not studied, the period was characterized by net aggradation $(0.11 \mathrm{~m})$. This means that, the erosional period of 2016-2018 was characterized by serious loss $(32 \mathrm{~cm})$ in bar elevation, which was only marginally compensated $(<2 \%)$ by the marginal aggradation in 2018-2019. This relates to the hydrological characteristics, as in the erosional period, the duration of low water stages increased and that of the high stages decreased. The importance of low stages in the erosion of the bar is well reflected by the pattern of the elevation changes, as always, the lower lying zone of the point-bar experienced greater erosion. In contrast, Ányás had an alternating erosion- accumulation sequence. In this case, clear correlation with low and high stages could not be found.

Direct and indirect human impact influences the development of the studied bars. Both studied point-bars are within the upstream sinuous section of the Lower Tisza River. The higher sinuosity of this section of the river accounts for the presence of more active bank processes (Kiss et al., 2019), as the thalweg runs close to the concave bank, thereby creating favorable conditions for bank erosion and point-bar formation on the opposite bank. However, the opposite bank of the point-bar at Csongrád was revetted in 2014, while the point-bar at Ányás is without direct human impact, and the opposite bank is intensively eroding, as it was presented previously. The point-bar in the free meander (at Ányás) reflects the existence of erosional and depositional cycles, regardless of hydrological changes. It can be explained by the fact, that the erosion of the concave bank created favorable conditions (wide channel) for the development of the bar on the convex bank which translates and migrates downstream. On the contrary, at the revetted section at Csongrád, the point-bar develops in a confined channel, which is characterized by incision (Amissah et al., 2017, 2018). This incision also affects the point-bar's surface, lowering it, though smaller in-channel flood waves might deposit some material on the surface. At Csongrád, the river was heavily constrained by cut-offs and bank stabilization, which began in the late 19 th century. The construction of revetment along the concave bank close to the confluence with the Körös River and the presence of the confluence seem to have affected the morphodynamics of this river section. With river confluences known to be geomorphological nodes which play an important role in the river's morphological evolution (Dixon et al., 2018), it may have contributed to the sediment dynamics both on the bar and downstream of the bar thus, distorting the natural evolution of the pointbar. 


\section{Conclusion}

The erosion of banks and the development of point-bars refer to the equilibrium status of rivers thus, the changes in these processes might indicate future channel changes. In the morphology of the meandering Lower Tisza River, these processes refer to a loss of equilibrium. Based on our previous study (Amissah et al., 2018), the Lower Tisza has transformed from a meandering river by river regulation works. The intensive natural near bank processes have been reduced due to the construction of revetments aiming to stabilize banks. However, the channel is incising as a response to artificial cutoffs and revetments which increased the stream power (Kiss et al., 2019). This is responsible not only for the intense bank erosion of the concave banks, but also for the erosion of the still existing active point-bars of the Lower Tisza. Our study proved that point-bars, especially those with revetments on their opposite banks are declining. Therefore, most of them have already been lost and the remaining ones will soon disappear.

Only those point-bars which are in free meanders might survive. Based on our case study, such a point-bar follows the seasonal variations in hydrology and bank erosion on the opposite bank, representing cyclic deposition and erosion of sediments on its surface. Although the geomorphic processes are variable, and our research has temporal and spatial limitations based on the size of the Lower Tisza River and the period of adjustment of the river after regulations, the results of this research have implications for future river management. Based on the active processes it could be assumed, that most active point-bars will be lost (eroded) with the exception of those which are without direct human impact. The process will be accelerated if new revetments are built and the collapsed ones are restored. However, it would be imperative for river managers to preserve the natural environment and the sensitive ecosystems created by these active bank processes by the possible restoration of some bank processes by the removal of hard bank stabilization structures. Management of the river system should gradually refocus on soft engineering measures and find ways of reviewing existing management schemes to reflect this new shift in ideology, with an exhortation to engineers as indicated by Lawler (1993) to adopt geomorphic methods in river management schemes as they may lead to improved solutions.

\section{Acknowledgement}

This research was funded by the Hungarian Research Fund (OTKA 119193). Special thanks to J. Nagy, R. Kispál and D. Kiss who helped in the field measurements.

\section{References}

Amissah, G.J., Kiss, T., Fiala, K., 2018. Morphological Evolution of the Lower Tisza River (Hungary) in the 20th Century in Response to Human Interventions. Water 10, 884.

Amissah, G.J., Kiss, T., Fiala, K., 2017. Centurial Changes in the Depth Conditions of a Regulated River: Case Study of the Lower Tisza River, Hungary. Journal of Environmental Geography 10, 41-51.

Bertalan, L., Rodrigo-Comino, J., Surian, N., Šulc Michalková, M., Kovács, Z., Szabó, S., Szabó, G., Hooke, J., 2019. Detailed assessment of spatial and temporal variations in river channel changes and meander evolution as a preliminary work for effective floodplain management. The example of Sajó River, Hungary. Journal of Environmental Management 248, 109277.

Blanckaert, K., Duarte, A., Chen, Q., Schleiss, A.J., 2012. Flow processes near smooth and rough (concave) outer banks in curved open channels. Journal of Geophysical Research: Earth Surface 117.

Church, M., Rice, S.P., 2009. Form and growth of bars in a wandering gravel-bed river. Earth Surface Processes and Landforms 34, 1422-1432.

Cosma, M., Ghinassi, M., D’Alpaos, A., Roner, M., Finotello, A., Tommasini, L., Gatto, R., 2019. Point-bar brink and channel thalweg trajectories depicting interaction between vertical and lateral shifts of microtidal channels in the Venice Lagoon (Italy). Geomorphology 342, 37-50. 
Department of Natural Resources and Water, 2006. What causes bank erosion? [WWW Document]. URL https://www.qld.gov.au/_data/assets/ pdf_file/0033/67677/what-causes-streambed-erosion.pdf

Dietrich, W.E., Smith, J.D., 1983. Influence of the point bar on flow through curved channels. Water Resources Research 19, 1173-1192.

Dixon, S.J., Sambrook Smith, G.H., Best, J.L., Nicholas, A.P., Bull, J.M., Vardy, M.E., Sarker, M.H., Goodbred, S., 2018. The planform mobility of river channel confluences: Insights from analysis of remotely sensed imagery. EarthScience Reviews 176, 1-18.

Eke, E., Parker, G., Shimizu, Y., 2014. Numerical modeling of erosional and depositional bank processes in migrating river bends with selfformed width: Morphodynamics of bar push and bank pull. Journal of Geophysical Research: Earth Surface 119, 1455-1483.

Galia, T., Škarpich, V., 2013. Coarse Bed Sediments in a Headwater Channel as Indicators of Fluvial Processes and Slope-Channel Coupling: A Case Study from the Carpathian Mountains (Czech Republic). Moravian Geographical Reports 21, 2-11.

Ghinassi, M., Ielpi, A., Aldinucci, M., Fustic, M., 2016. Downstream-migrating fluvial point bars in the rock record. Sedimentary Geology 334, 66-96.

Hagstrom, C.A., Leckie, D.A., Smith, M.G., 2018. Point bar sedimentation and erosion produced by an extreme flood in a sand and gravel-bed meandering river. Sedimentary Geology 377, 1-16.

Hickin, E.J., 1974. The development of meanders in natural river-channels. American Journal of Science 274, 414-442.

Hickin, E.J., 1969. A newly-identified process of point bar formation in natural streams. American Journal of Science 267, 999-1010.

Hodskinson, A., Ferguson, R.I., 1998. Numerical modelling of separated flow in river bends: model testing and experimental investigation of geometric controls on the extent of flow separation at the concave bank. Hydrological Processes 12, 1323-1338.

Hooke, J.M., 1980. Magnitude and distribution of rates of river bank erosion. Earth Surf. Process. 5, 143-157.

Hooke, J.M., 1979. An analysis of the processes of river bank erosion. Journal of Hydrology 42, 39-62.

Ikeda, H., 2013. Sedimentary Controls on Channel Migration and Origin of Point Bars in Sand-Bedded Meandering Rivers, in: River
Meandering. American Geophysical Union (AGU), pp. 51-68.

Iwasaki, T., Shimizu, Y., Kimura, I., 2016. Numerical simulation of bar and bank erosion in a vegetated floodplain: A case study in the Otofuke River. Advances in Water Resources, Numerical modelling of river morphodynamics 93, 118-134.

Kasse, C., Bohncke, S.J.P., Vandenberghe, J., Gábris, G., 2010. Fluvial style changes during the last glacial-interglacial transition in the middle Tisza valley (Hungary). Proceedings of the Geologists' Association, Fluvial records as archives of human activity and environmental change 121, 180-194.

Kasvi, E., Vaaja, M., Alho, P., Hyyppä, H., Hyyppä, J., Kaartinen, H., Kukko, A., 2013. Morphological changes on meander point bars associated with flow structure at different discharges. Earth Surface Processes and Landforms 38, 577-590. https://doi.org/10.1002/ esp.3303Lóczy $\quad$ D., 2018. Természeti és antropogén tényezők szerepe az Alsó-Tisza menti partfal-instabilitások kialakulásában. FK 142, 328-343.

Kiss, T., Amissah, G.J., Fiala, K., 2019. Bank Processes and Revetment Erosion of a Large Lowland River: Case Study of the Lower Tisza River, Hungary. Water 11, 1313.

Kiss, T., Blanka, V., Andrási, G., Hernesz, P., 2013. Extreme Weather and the Rivers of Hungary: Rates of Bank Retreat, in: Loczy, D. (Ed.), Geomorphological Impacts of Extreme Weather. Springer Netherlands, Dordrecht, pp. 83-98.

Kiss, T., Fiala, K., Sipos, G., 2008. Alterations of channel parameters in response to river regulation works since 1840 on the Lower Tisza River (Hungary). Geomorphology 98, 96-110.

Lai, Y.G., Greimann, B.P., 2008. Modeling of Erosion and Deposition at Meandering Channels, in: World Environmental and Water Resources Congress 2008. Presented at the World Environmental and Water Resources Congress 2008, American Society of Civil Engineers, Honolulu, Hawaii, United States, pp. 1-11.

Lászlóffy, W., 1982. A Tisza: Vízi munkálatok és vízgazdálkodás a tiszai vízrendszerben.

Lawler, D.M., 1993. The measurement of river bank erosion and lateral channel change: A review. Earth Surface Processes and Landforms 18, 777-821.

Luppi, L., Rinaldi, M., Teruggi, L.B., Darby, S.E., Nardi, L., 2009. Monitoring and numerical modelling of riverbank erosion processes: a case study 
along the Cecina River (central Italy). Earth Surface Processes and Landforms 34, 530-546.

Mezősi, G., 2017. The Physical Geography of Hungary, Geography of the Physical Environment. Springer International Publishing.

Moody, J.A., 2019. Dynamic relations for the deposition of sediment on floodplains and point bars of a freely-meandering river. Geomorphology 327, 585-597.

Nagata, T., Watanabe, Y., Yasuda, H., Ito, A., 2014. Development of a meandering channel caused by the planform shape of the river bank. Earth Surface Dynamics 2, 255-270.

Nicoll, T.J., Hickin, E.J., 2010. Planform geometry and channel migration of confined meandering rivers on the Canadian prairies. Geomorphology 116, 37-47.

Pyrce, R.S., Ashmore, P.E., 2005. Bedload path length and point bar development in gravel-bed river models. Sedimentology 52, 839-857.

Rinaldi, M., Mengoni, B., Luppi, L., Darby, S.E., Mosselman, E., 2008. Numerical simulation of hydrodynamics and bank erosion in a river bend. Water Resources Research 44.

Rusnák, M., Lehotský, M., Kidová, A., 2016. Channel migration inferred from aerial photographs, its timing and environmental consequences as responses to floods: A case study of the meandering Topla River, Slovak Carpathians. Moravian Geographical Reports 24, 32-43.
Schuurman, F., Shimizu, Y., Iwasaki, T., Kleinhans, M.G., 2016. Dynamic meandering in response to upstream perturbations and floodplain formation. Geomorphology 253, 94-109.

Sipos, G., Kiss, T., Fiala, K., 2007. Morphological alterations due to channelization along the lower Tisza and Maros rivers (Hungary). Geogr. Fis. Dinam. Quat. 30, 239-247.

Thorne, C.R., 1991. Bank erosion and meander migration of the Red and Mississippi Rivers, USA. Hydrology for the Water Management of Large River Basins (Proceedings of the Vienna Symposium), 301-313.

Wallick, J.R., Lancaster, S.T., Bolte, J.P., 2006. Determination of bank erodibility for natural and anthropogenic bank materials using a model of lateral migration and observed erosion along the Willamette River, Oregon, USA. River Research and Applications 22, 631649.

Wu, C., Ullah, M.S., Lu, J., Bhattacharya, J.P., 2016. Formation of point bars through rising and falling flood stages: Evidence from bar morphology, sediment transport and bed shear stress. Sedimentology 63, 1458-1473. 